\title{
Human Rights and Democratic Development in Nigeria: The Missing Link
}

\author{
Akani Christian \\ Political Science Department, Ignatius Ajuru University of Port Harcourt, Rumuolumeni, \\ Rivers State, Nigeria \\ E-mail: christian.akani@yahoo.com
}

Received: July 25, 2014 Accepted: August 19, 2015 Published: August 20, 2015

doi:10.5296/jsss.v3i1.8178 URL: http://dx.doi.org/10.5296/jsss.v3i1.8178

\begin{abstract}
Human rights have become a buzzword in the $21^{\text {st }}$ century. Apart from its global legitimacy, it has become an index of measuring the level of good governance and has an organic link with development. Development here connotes the capacity of a people to reproduce themselves within a social context. All through ages, human rights have engendered democratic development principally because of a sustained social action, in most cases leading to the payment of the supreme sacrifice. After all, freedom is not given by the exploiter to the exploited on a platter of gold. Stupendously, in spite of flagrant violations of human rights by successive governments in Nigeria, it has not triggered a sustained social action to ensure democratic development. Although, some sparing efforts have been made, they fizzle out over time. This negative attitude has heightened Government impunity and deceit. Therefore, the focus of this paper is to examine why Nigerians are not conscious of their rights. ? Why is government not accountable to the people? In carrying out this task, the qualitative method of data collection was used with an emphasis on triangulation. It was discovered that Nigerians are not dogged in the protection of their rights, thinking that development can come to them by the benevolence of government. It recommends that Nigerians should not agonize, but doggedly and consistently organize to demand and protect their rights, at all times. Anything less will make democratic development elusive.
\end{abstract}

Keywords: Human rights, Democratic development, Good governance, Enlightenment, State

\section{Introduction}

Since the end of the Second World War (WWII), and the epoch-making United Nations Declaration of Human Rights [UNDHRs] on December 10, 1948, observance of human rights have become a template to measure the performance of governments all over the world. For 


\section{1l Macrothink}

Journal of Social Science Studies

ISSN 2329-9150

2016, Vol. 3, No. 1

civil society groups and those desirous of upholding the respect and sacredness of human dignity, it has become a regular mantra. Hence, it is not strange to find human rights activists in all the disciplines, especially social sciences, law and the environment. Its etymology can be traced to humanity. It arose the moment humans became conscious of their consciousness. After, nature reveals its secrets only to educated minds (Kirilenko \& Korshunova, 198), because '... men's consciousness is the consequence of their life in society' (Guryev, 1990). Ancient societies such as the Greek city-states and the Roman empire institutionalized a social stratification which reduced many people like women and slaves to inferior status. While the while the State was seen to exist for all, in praxis it existed only for the few. This assumption was a precipitate of the slave mode of production in those societies. Women and slaves were regarded as instruments of possession.

But from the thirteenth century onwards, knowledge of human rights started gaining some acceptance even among the rulers. This development was facilitated by the rising consciousness arising from the social activity of the epoch. It was within this context that on June 15, 1215 King John Lockland signed the historic Magna Carta, which checkmated arbitrary rule, and in 1689 the British Bill of Rights came into existence after the Glorious Revolution in 1688.

\section{Statement of the Problem}

This paper is to examine why democratic development has eluded Nigerians since political independence. Most surprising is the fact that the country is endowed with immeasurable mineral resources and enviable human capital.

Many scholars believe that this situation can be attributed to the country's colonial albatross, and the nature of political competition which is rooted in primordial identity. Plausible as this explanation may sound, it does not constitute a hindrance to the growth of popular consciousness. Therefore, this paper will examine,

i why the violation of human rights has not galvanized the people to action?

ii what is responsible for the docility of Nigerians in the protection of their rights?

iii Is it possible for democratic development to take place in a society without a struggle?

\section{Objectives of the Study}

In view of the fact that democracy has become an essential component of modern governance, its comprehension has become imperative. This is largely because democracy creates the enabling environment for development to triumph.

Therefore, the objectives of this paper is to establish that;

i There can be no democratic development in any Polity without the people playing the role of a trigger.

ii Human rights and democratic development cannot be won by mere wish.

iii Nigeria's underdevelopment status is because the exploited have failed to serve as a check on the rulers.

\section{Literature Review}

The discourse on human rights has gained prominence because as Mutua (2008) pointed out 'ours is the age of rights'. Human Rights is the idea of our time, the only political, moral idea 


\section{MInstitute ${ }^{\text {Mimk }}$}

that has received universal acceptance. This global appeal makes it imperative that it must be comprehended by the rulers and the ruled. Human rights pertain to humans, and no production or reproduction can take place without their full enjoymentt. It is natural and therefore inherent in human beings regardless of sex, race, creed, ethnicity and socio-economic standing. Therefore, 'cultural relativism cannot superintend over it because the inherent dignity and the equal and inalienable rights of all members of the human family is the foundation of freedom, justice and peace in the world' (Callaway \& HarrelsonStephens, 2007). Locke (1993) whose ideas shaped the Enlightenment and individual liberty in the seventieth century, vehemently stated that 'the natural liberty of man is to be free from any superior power on earth and not to be under the will or legislative authority of man, but to have only law of nature for his rule. The liberty of man in society is under no other legislative power, but that established by consent in the commonwealth'. Locke (1993) went on to stress that "Man being, as has been said, by nature all free, equal and independent, no one can be put out of his estate and subjected to political power of another, without his consent". Locke's (1993) concern about individual Liberty and freedom was also emphasized in Mill's Liberty. Mill (1859) was apprehensive about the tyranny of the majority, which may stultify the efflorescence of personal freedom. Therefore,

Man collectively or individually should not interfere with the liberty of activities of anyone except for self-protection. Power could only be rightly exercised on someone to prevent harm to others. Not even his own good is sufficient reason to restrain him. He could be persuaded but not restrained. Only when it concerns others can he be restrained. over himself, his body, and his mind, the individual is sovereign (Nwokolo, 1988:168-9).

It is within this context that human rights can be regarded as

...rights inherent in individual as rational free willing creatures, not conferred by some, positive law nor capable of being abridged by positive law Anifowose and Enemuo, 1999:147).

The basic rights of man cannot be arbitrarily abridged by a State because they 'appertains to the nature of man (and) cannot be annihilated by man' (Paine, 1996). Lask (2004) declared that 'rights, in fact are those conditions of social life without which no man can seek, in general, to be himself at his best'. It is a strong regulator of anti-people rule and man's inhumanity to man. Hence, it is 'universal, non- partisan, acultural and non-ideological (Mutua, 2008). It is not amazing that the corpus of United Nations Covenants on Human Rights (UDHR) the International Bill of Rights emphasize the vital importance of the rights of human beings. For instance, article 1 of the UDHR states that 'all human beings are born free and equal in dignity and rights. They are endowed with reason and conscience and should act towards one another in a spirit of brotherhood'. Article 5 of the Vienna Declaration and Programme of Action in 1993 also noted that 'all human rights are universal, indissoluble, interdependent and interrelated'. What these Instruments mean is that no aspect of human rights can be proscribed, protected and promoted to the exclusion of others. The 1989 French Revolution and the American Independence Declaration in 1776 clearly states the inviolability of human rights. Article 1 of the French Revolution whose enduring slogan was Freedom, Liberty and Equality noted that 'men are born, and always continue, free and equal in respect of their rights ... (Paine, 1996). The American Declaration, unequivocally averred 
that

We hold these truths to be self-evident, that all men are created equal, that they are endowed by their creator with certain inalienable rights that among these are life, liberty and the pursuit of happiness. That to secure these rights, governments are instituted among men, deriving their just powers from the consent of the government. That whenever any form of government becomes destructive of these ends, it is the right of the people to alter or to abolish it, and to institute a newGovernment... (Anifowose \& Enemuo, 1999).

The above quote reinforces Locke's (1993) charge to the civil society on arbitrary Governments, Human rights are the inalienable rights of human beings without which they cannot fulfill their neutral and social obligations to the society. Like human rights, democracy has become an essential ingredient of good governance. Democracy is a combination of two Greek words - Demos (people) and Kratia (Rule). Anglicized as democracy means popular or people's rule. It implies the right of the people to participate in the process of governance for the enjoyment of the social dividend thereof. It entails the equality of opportunities to participate in making decisions and quality of obligations to participate in carrying them out once they are made until they are revised (Omoruyi, 1994). Appardorai (2004) defines democracy as respect for the value of individual personality and provides institutions for the expression and in the last analyses, the supremacy of the popular on baric questions of social direction and policy. It 'enables the individual to be lifted above the narrow circle of his egoism, and broadens his interest. The individual becomes interested in his country and develops a sense of community and responsibility' (Omoruyi, 1994). On the other hand, it also beholds on the State to obey and respect the wishes and aspirations of the people for harmony and smoothness. This lies the rationale for accountability, rule of law and transparency. This point cannot be treaty with brevity because,

Every government must submit itself to the judgment of those who feel the consequences of its acts. The reason for such submission is that simple historical facts that unconditional power has always proved, at least ultimately, disastrous to

those over whom it is exercised (Laski, 2004).

It is important to state that humanity did not wake up to experiment democracy, rather it is the aftermath of years of rigorous and contentious struggle in the society between the rulers and the ruled.

... as a system of government based on majority rule and which emphasizes that the best form of government is one of limited authority ... with checks and limitations for the protection of minorities ...' (Ike et al., 2007).

Its global appeal cannot be disputed as every State within the global community assiduously strive to become democratic. This is because there seem to be no alternative to popular rule. According to Nnoli (2003).

to all intents and purposes democracy represents the highest achievement of mankind, so far, in its worldwide struggle for progress in social and political relations. It is a product of the sweat, toil, creativity, blood and sacrifice of millions of people across space and time in the human struggle for a better life.

A democratic state has the capacity to lay a solid foundation for development. Development 
in this paper is not growth or robust economic indicators, rather it is the empowerment of the people to subdue their environment for their collective enjoyment and social reproduction. Rodney(1972) defines it as '... increased skill and capacity, greater freedom, creativity, self-discipline, responsibility and material wellbeing' . It is transitional, progressing towards a desired end in a teleological nature. The end may become the beginning of another process which ultimately enhance the quality of life and capacity of the human capital. Hence, it is evaluative and '... involves not only a change in but also a change which has direction .According to Peek and Hartwick (1999)

development means using the productive resources of society to improve the living conditions of the poorest people...it entails human emancipation, in two senses; liberation from the vicissitudes of nature through advanced technology and self-emancipation...

Development is human centered, hence the United Nations Development Programme (UNDP) declared that it is about people, about people responding their choice to live full, creative lives with freedom and dignity (Nault, 200). Since it is anchored on the improvement of the quality of life and happiness of the people, it is not stupendous that poverty eradication and protection of the environment have become main themes in the discourse about development. Development has to be more concerned with enhancing the lives we lead and the freedom we enjoy (Todaro \& Smith, 2004). Therefore, every development endeavour must make a qualitative turn-around in the living conditions of the populace, otherwise it becomes an exercise in futility. It must not be externally-imposed, rather it must evolve from the willingness of the people. As Ake (2001) pointed out, it must not 'ignore the specificity and historicity' of the people .In a nutshell, every development policy must be people-oriented. It must be geared towards affecting and improving the quality of life of a people including ensuring their human security.

\section{Theoretical Framework}

Marxist Political Economy is the appropriate theory for this research. This is largely because of its objectivity and holistic approach to social problems. Its materialistic foundation anchored on dialectic process abhors subjective assumptions and metaphysical abstraction. This invariably, leads to an effective understanding of the complex social world. Marx (1984) clearly stated that comprehending the anatomy of civil society can only be sought in political economy. He further stated that a man's consciousness is determined by his position in the social production of material resources. It was against this backdrop, that Ake (1981) stated that the benefit of this approach is that it encourages dialectical thinking and accepts change as ubiquitous in the society. Therefore, this theory will assist in the understanding of the social forces at play in Nigeria, and their effect on the people.

\section{Human Rights and Development. The Nigerian Experience}

The Nigerian State has found itself in a pitiable condition because of its obvious inability to be on the path of democratic development. This is largely because of flagrant abuse of and denigration of human rights. Nigeria emerged as a sovereign State in the global comity of States on October 1, 1960 with bloated hope and high optimism. In fact, Nigeria became the glittering star within the galaxy of independent African states. This was predicated on its resourceful human capital and unrivalled natural endowment. 


\section{Macrothink}

Regrettably, these became a mirage, and the hopes turned to rising frustration and despair. With a disarticulated, disjointed and externalized economy and presided over by a bourgeois class whose legitimacy to rulership was the control of political power. Ake (1981) noted that this class was imbued with neo-colonial values and interested in the perpetuation of a 'capitalist, docile and dependent political agenda'. With the relentless use of politics for economic advancement, the stage was set for acrimonious and cataclysmic political development, and gradually the country became a mere empty shell incapable of providing the basic needs of the populace. The First Republic 1960-1966 vividly demonstrated the weakness of the Post Colonial State. The ruling class ensured the triumph of a de-democratization process, reduced the people to appendages in the political process and engaged in a rancorous relationship which affected political followership and the patriotic vision of the people. Gradually, a political culture evolved in which the '... control of Nigeria's central government is the birth right of a few' (Amuwo et al., 1999). The epoch witnessed a heightened political violence and intolerance. Dudley(1982) noted that the two 'elections did show that for the political elite power was an end-in-itself and not a means of realization of some greater 'good' for the community, and whatever the instrumentalities employed by the pursuit of power, such instrumentalities were legitimate'.

The aftermath was that since the ruling class were preoccupied with possessive individualism, the essential elements of democracy - 'equality, sovereignty of the people, respect for human life, rule of law, and liberty of the individual' was jettisoned (Anifowose \& Enemuo, 1999). In this hostile political environment, opposition to officialdom was suppressed and persons portrayed as "enemies" and 'antagonists" of the state were visited with the State's instruments of coercion. In the late 1950's the Federal Government evoked the danger of 'contacts with, and beliefs in communist lies'. The Government noted that

We are determined that, while we are responsible for the government of the federation of Nigeria and for the welfare of its people, we shall use every means in our power to prevent the infiltration of communism and communistic ideas into Nigeria (Falola, 2002).

This was the background for the intervention of the military. Mindful of all the contradictions that engulfed the First Republic and the attendant negative impact it unleashed on the Polity, the military decided to forcefully intervene to halt the aimless drift on January 15, 1966. Unfortunately, this singular act set in motion a trail of unforgettable anti-democratic policies and popular disempowerment. Delivering a judgment on the treason trial against Chief Awolowo and some members of Action Group Party, Justice Sowemimo summarized the political character of the First Republic. As he put it,

On the evidence before me it would appear that politics generally in Nigeria has been conducted with a certain amount of bitterness and vindictiveness. On the evidence it appears that a person who belongs to a party becomes an enemy of another who belongs to another party. ... the shortest cut to affluence and influence is through

politics. Politics means money and money means politics (Akani, 2001).

Justifying the reason for their takeover, Major Chukwuma Nzeogwu noted that

... our enemies are the political profiteers, swindlers, the man in high and low places that seek to keep the country permanently divided... those that have corrupted our society and put 
the Nigerian political calendar back by words and deeds (Nwankwo, 1999).

Filled with a mission of redemption and corrective agenda, the military became dominant in the country's political governance from 1966 to 1979, and December 31, 1983 to May 29, 1999. Within this epoch, a militarized political culture was hoisted on Nigeria; consequently a solid foundation was laid for democratic bastardization. The constitution which guaranteed the basic rights of individuals was abrogated, popular participation in governance abridged and an exclusive political culture was instituted. The contradictions inherent in this political arrangement snowballed into needless coups and counter-coup d'état which claimed the lives of many military officers and civilians. By the time it handed over power to civilians in 1999; it bequeathed a legacy of unspeakable kakistocracy to the country just as the country's dream was aborted (Ohuabunwa, 2010).

The military has returned Nigeria to the dark ages; the triumph of irrationality, corruption, mediocrity and the negation of all norms of dialogue and consensus, making it possible for the discredited ethnic, religious and regional warlords to be rehabilitated and for atavistic, sectional and opportunistic interests to emerge in all sectors at the expense of popular democratic interests (Onyesoh \& Omeje, 2000).

The anti-democratic order systematically facilitated the country's retrogression to authoritarianism. This was legitimized by draconian legislations and these empowered officialdom to unilaterally detain people without recourse to judicial process. Such legislations included, the State Security (Detention of Persons) Decree 2 of 1984, Decree No. 12 of 1986 Decree No. 30 of 1988 and Decree No. 3 of 1990... (Ogbonda, 2003). Under the military, the country's vibrant, ebullient and robust press was gagged and limited at will. This also included persons whose political and economic views diametrically opposed that of the government.

Between 1985 and today... he (Babangida) has promulgated 57 decrees to govern his transition to civil rule with 1,174 sections, not to count the sub-sections. In essence if you want to decide what the law is about the transition programme, you will have to be looking for a needle in a hay sack. (Nwankwo, 1993).

Apart from the $\$ 12.4 \mathrm{~b}$ of gulf oil which General Babangida could not account for, Maier (2001) noted that oil licenses were granted to indigenous companies run by IBB cronies. As for General Sani Abacha, his looting of the treasury was legendary. The military ensued a combative governance and privatized the commanding height of the economy. Undoubtedly, this engendered a process of rabid accumulation of wealth and the concomitant internal contradictions manifested in coups and forced retirement. Nwankwo's (1999) meticulously described the shameless looting spree by successive governments which drastically reduced the capacity of government to provide basic needs of the people. It was therefore not amazing that the nation's military soon degenerated from its pedestal of social amelioration, humanistic affirmation and creativity into the whirlpool of organized looting of the national treasury (Nwankwo, 1999). By the $21^{\text {st }}$ century, Nigeria is still weighed down by a culture of impunity, mind boggling munificence, grand corruption, electoral fraudulence and human insecurity. Since the ruling class vehemently loath the prospect of loosing political power, electoral contests have become a fight of the titans. This is epitomized in the general elections of 1979, 1983, 2003, 2007 and 2011. Hence, there is neither any semblance of internal 
democracy nor the parties propelled by any ideological commitment. The dominant motif of participating in politics is far from good governance, but for pirate accumulation of wealth. In the 2006, ward congresses, Genyi (2009) noted that;

in virtually every state, the ward congress turned out to be a gun-and-dagger game in which the most armed went home with victory. It was an atavistic return to all that is ugly in the nation's democracy. Not once was the quality of candidates an issue. Rather what appeared to count primarily were narrow vested interests. Certain personalities in the party who loomed larger than the party itself insisted that their own hand picked candidates must take the party ticket. In many states, such persons had their way, despite protests by the majority.

The lack of commitment to democratic electoral ideals, cohesion and an agenda for development have made persons who occupy public offices through party machinery to engage in grand corruption without any tinge of remorse. It is therefore, not stupendous that corruption has become a fundamental principle of governance in the $21^{\text {st }}$ century. The case of former Governor of Delta state, James Ibori convicted in London for graft by a British court, former Governors of Edo State, Lucky Igbinedon ,convicted by an Enugu Federal High Court. He paid N 3.6 million as fine, the former Bayelsa state Governor, Dieyepreye Alamieyesiegha, and the series of corruption charges against public officers by the Economic and Financial Crime Commission (EFCC), attest to the ubiquity of the virus of corruption in the country's political fabric. This was how the enormous amount of money earned by the Nigerian State over the years found its way in the private pockets and accounts of public officials. From 1965 to 2000, Nigeria earned about \$300b from oil, within 1990 to 1993 she got $\$ 199.3$ b (Akani, 2004). It is estimated that 80 percent of hundreds of billions of dollars of oil revenue which have been derived in Nigeria has accrued to only 1 percent of the population (Carmody, 2011). This is the genesis of resource- curse and social discontent in the Niger Delta region of the country. In fact,

...the oil which brought so much wealth to the nation and those in power, brought much, poverty, disease, death, loss of livelihood etc., to the people of oil bearing communities (Ibodge, 2008).

Today, the incidence of poverty is $70 \%$, in 1970 life expectancy was 54 years but this year (2010) it is 48 years. In 1970 gross unemployment level was $15 \%$ but this year (2010), it is about 25\% (Ohuabunwa, 2010). Electoral contest which is the most important characteristics of democracy and the channel through which the supremacy and participation of the people is measured is dominated by the ruling class and their cronies. This gives room for easy access to the commonwealth and protected with state apparatus. Elections which should have been a strong instrument of deepening democracy have turned out to be a sham and a jamboree of the bourgeoisie to perpetuate their rulership of the state. Nnoli (2003) opined that

to negate democracy is to negate this history of struggle, toil and sacrifice and the contribution of this struggle to human progress ... a negation of election is a negation of democracy generally

When the feelings and aspirations of the people are marginalized and suppressed for the interest of a few, such a Polity cannot be said to be democratic. As Laski (2004) put it, 'in any state where there is an absence of the critical spirit in the attitude of citizens to their rulers, 
the preservation of rights is a difficult matter'. It is against this backdrop that Ake (1996) noted that,

democracy cannot thrive amidst such docility and crass opportunism. Those who do not take human dignity serious cannot benefit from democracy. Nor can they take the democratic claims seriously, for these claims are ultimately about human dignity.

As the basic needs are far beyond the reach of the people, a Hobbesian environment based on survival of the fittest is introduced. This explains the insistent human insecurity epitomized in the Boko Haram and Niger Delta insurgence. With a mass of hopelessly frustrated people wallowing below the breadline level, their contribution to democratic development and empowerment becomes a mere rhetoric. Popular empowerment which is an essential prerequisite of democracy has become a mirage in the country. A people cannot be empowered when the leadership consciously creates a scenario for the pauperization of the citizens and ensures the institutionalization of a de-democratization process. Empowerment is

... a form of socio-economic and political restructuring which removes the locus of power, and enables the currently disadvantaged to meet their basic needs, fully participate in decision making, and provide opportunities to challenge internal and external (oppression) (Amunwo et al., 1999).

As Nigerians are economically asphyxiated and bereft of the capacity to challenge officialdom, the fashionable alternative is to play according to the behest of the custodians of state. In this scenario Ake[1996:18] noted that democracy cannot thrive, because 'a society of beggars, parasites and bandits cannot develop, it cannot know peace or stability, and it cannot be democratic. It can only gravitate endlessly, as we are going in material poverty and moral regression. It is, therefore not strange to see many Nigerians parroting and praise - singing the tunes of government for recognition. Nevertheless, it is important to state that,

men who are prevented from thinking as their experience teaches them will soon cease to think at all. Men who cease to think cease also to be in any genuine sense citizens (Laski, 2004).

There is no gainsaying that human rights are linked with democratic development, but this cannot take place unless the exploited mass take their destiny in their own hands. Fanon's (1963) admonition that 'each generation, must out of relative obscurity, discover its mission, fulfil it or betray it' comes to mind. A peep into global history will reveal that social development at each epoch did not emerge because of the altruistic caprice of the rulers; rather it is a consequence of the consistence and sustained efforts of the people to ensure a qualitative existence by checking the excesses of governors.

Right from the Roman Empire when the slaves revolted against their in human misery to the twentieth century, the contradictions between the governed and governors have ultimately triggered a trail of empowerment in the society. While the slave revolts and other widespread rebellion snowballed into the dawn of a new epoch, the Glorious Rebellion of 1688 in Britain, French Revolution of 1789, and the United States of America (USA) Declaration of Independence of 1776 ushered in a new era in the inherent rights of man to protect his/her life, and property from tyranny and absolutism. The slave revolts which culminated into the civil 
rights movement of the 1960s in the USA was a precipitate of the commitment, dedication and rising consciousness of the exploited blacks to unreservedly smash their yoke of inhumanity. The lesson from these developments is that the people must compel constituted authority to act within the bounds of law. Paine (1996) pointed out that 'Sovereignty, as a matter of right, appertains to the nation only, and not to any individual, and a nation has at all times an inherent, indefeasible right to abolish any form of Government it finds inconvenient and to establish such as accords with its interest, disposition, and happiness .

The epoch making United Nations Declaration of Human Rights (UNDHR) on December 10, 1948 was a sharp reaction to the carnage, barbarity, destruction, the holocaust and the iniquitous actions of States in the 1940s under the cover of State sovereignty. The underlying assumption is that human rights can only be appreciated and fulfil its historic mission if the people are galvanized to play their role. As Fanon pointed out; the masses should know that the government and the party are at their service. A deserving people, in other words a people conscious of its dignity is a people that never forgets these facts' (Fanon, 1963). Perhaps this was why Locke (1689) asserted that men are born free. Human freedom becomes meaningless unless it is jealously guarded, defended and promoted. It is, therefore, not strange that he advised the people to 'alter, amend, change or dissolve' any government that rules arbitrarily. In other words 'government based on consent, coupled with the right of the people to rebel was the best fence against rebellion' (Mukherjee \& Ramaswamy, 2005). Rulers must at all times be accountable to the people. As Laski (2004) opined:

power that is to say is always a trust and it is always held upon conditions. The will of the state is subject to the scrutiny of all who come within the ambit of its decision. Because it moulds the substance of their lives, they have the right to pass judgement, for it is the plain lesson of the historic record that the wants

of men only secure recognition to the point that ourselves save where we identify ourselves to our wants and desires.

Locke (1689), Laski (2004), Russel (1945), Nkrumah (1973), Marx and Engels (1848) have all come to the inevitable conclusion that development does not fall from the blues, but a function of the long struggle of the people. The universal call for revolution in the Communist Manifesto is predicated on the fact that exploited people have nothing to lose but their chains. They have a world to win. Hence, 'working men of all countries unite' (Marx \& Engels, 1961). The Enlightened Philosophers, noted that 'our aim is to gather all knowledge together so that our descendants, being better instructed may at the same time be happy and more virtuous' (Akani 2010). Society will witness a dearth of development if the people decide to retreat into cesspit of docility. Therefore, rational opposition of the marginalized is an essential ingredient of democratic development. It is against this backdrop that White and Hussey (1963) opined that 'the opposition sharpens government policy by its criticism and present abuse by its wastefulness. Open, candid and fearless opposition is an essential feature of (parliamentary) democratic government'. 'Every ruler needs a push to feel the pulse of the people at all times. But if taken for granted, a crack of tyranny begins to creep in. Rulers must be told that there is no permanent right to power. 'Every government must submit itself to the judgment of those who feel the consequences of its acts... because... unconditional power has always proved, at least ultimately, disastrous to those over whom it is exercised' (Laski, 
2004). Again, Laski (2004) warned that:

no community could hope to fulfil its purpose unless the will of its government were limited in a variety of ways. It must answer at stated period to those from whom it derives its powers. It must be powerless to touch certain fundamentals (of which freedom of speech is supreme example) without which the benefit of social life will not as a matter of history be widely shared among the mass of men.

While it is indubitable that Nigerians demonstrated their disaffection and rejection of military regime from 1983 and 1998, the enthronement of civil rule from 1999 has given the illusion of a democratic order. It also exposed the crass opportunism, lip-service commitment and uncoordinated agenda of the anti-military protest. The prevalent docility of the people has made the rulers manipulate them like pawns and puppets at their behest. This is the missing link in Nigeria's quest for democratic development. Many scholars have proffered myriad reasons for the profound slumber. Such reasons include ethnicity and lack of a vibrant working class. Nnoli (1971) noted that ethnicity is a strong tool in the hands of the custodians of state power to subvert democratic development. The poor development of a class consciousness has been attributed to the inherited colonial industrial policy. As an expression of social relations in the productive process, Lenin noted that 'classes are social groups of people one which can appropriate the labour of another owing to the different places they occupy in a definite system of social economy'. In Nigeria, the working class has become static, and lost its efficacy as a dynamic tool of social change (Imoagene, 1989). To remedy the situation a ... rapid industrialization (in Nigeria is necessary) in order to build a large working class. Plausible as these conclusions may sound, they still possess a limited utility in explaining the legendary docility of Nigerians. First, ethnicity is not a natural feature of Nigerian political lexicon, but it arose at a point in the historical development of Nigerian politics. It emerged with the abdication of the historic responsibilities of the State and will wither away if the State is made to be responsible and responsive to the people. 'The tenuous relationship between the Nigerian State and its subjects implied by these conditions is underscored by the indifference of the Nigerian state to welfare... Ethnic associations, religious groups, cooperatives, freemasonry has mushroomed in Nigeria filling the gap left by the State's indifference to social welfare (Falola, 2003). Second, to wait until Nigeria develops its productive forces through rapid industrialization is to wait for the Godot, and an affirmation to strictly conform to the European model of modernization. After all democracy. ...is a thing of the heart. It is not a matter of legislation alone; it must become part of one's inner feeling as well as conforming to universally subscribed norms and ways of doing things. Even in established democracies eternal vigilance must be the order of the day so that democratic rights of the people are not subverted by the strong, wealthy and the powerful (Osuntokun, 1997).

The main problem with the Nigerian people is their glaring lack of the consciousness that they have the inherent right to set limits for their rulers. They have failed to maintain internal vigilance and religiously guard against any infraction on their rights. It is amazing that a greater number of Nigerians do not know and not ready to know about the potency of the UNDHR, UN Covenants such as the Political and Civil Rights, and the Economic, Social and Cultural Rights. Section 1 of these instruments placed emphasis on the right of 
self-determination. Even those who are supposed to be the vanguard of social change have only become 'intellectual giants but moral dwarfs' (Omoregbe, 2003). Human rights activists in mind, but reformist in character, as Adi (2002) put it; 'proletariat in London and bourgeois in Lagos'. With the deepening erosion of educational standards, many students are quick to justify the status quo and willy-nilly internalize it's preferences. Today Nigerians have become more fatalistic and hoping for deus es-machina to salvage them from thraldom. Knowledge of human rights and the commitment to respect and uphold it ultimately translate to democratic development. This is through a conscious realization of the power and use of social consciousness. Gradually, it is becoming a sacrilegious crime to point out pitfalls of government and to subject public officers to accountability. Tightly blind folded by primordial parochialism, the people are made to believe the sophistry that a demand for good governance is 'to overheat' the polity. In this scenario, it is not stupendous to see rented crowds including students chanting the eulogy of a government that has demonstrated glaring incapacity to promote human rights, and ensure an improved Human Development Index. This explains the transience of all the civil society protests and limited achievements.

\section{Conclusion}

In this paper, we have demonstrated that there is a symbiotic relationship between human rights and democratic development. But this link cannot be objectified and appreciated by the society unless it is acted upon. History has demonstrated unequivocally that democratic development which is now the hallmark of modern States cannot be achieved on a platter of gold. It was a consequence of contradictory struggles which synthesized a new dawn. One salient fact about change is the consciousness of the people. It is a dynamic force of social change, and requires unwavering commitment to make the rulers respond to the people's sufferings. This is true of the Civil Rights Movement, the socio-political revolutions in Europe and North America. Today the strict guidance of human rights by rulers of those societies has been translated into development and modernity. Indeed, development cannot be earned by mere wish.

This is the missing link in Nigeria. Nigerians do not realize that they have the inherent right to re-direct their destiny. They also lack the commitment and dedication in checkmating the excesses of rulers. It is not surreal, therefore, that in spite of the mind boggling infractions of rulers and violations of rights with impunity, Nigerians seem to turn their eyes the other side. In fact, they are seen as the happiest people in the world and believing that arbitrariness will come to pass like the Hegelian movement of ideas. The aftermath is the dogmatic acceptance of oppression of a cruel government. Indeed,

a society which is afraid to confront itself, a society unwilling or unable to air its stinking bed linens for the public to see, a society afraid of trying public figures at the bar of public opinion cannot be considered a democratic society. (Dukor, 2003)"

Therefore, Nigerians must wake up from their long slumber. The civil society which is that intermediary entity, standing between the private sphere and the State, should galvanize Nigerians to action by acting collectively in a public share to express their interest, passion ... make demands on the state and hold them accountable (Kukah, 2003). Remmick (2011:153) noted that, "we have also come here today to affirm that we will no longer sit idly by agonizing aggravation and want on others to provide our freedom ... freedom is never 
voluntarily granted by the oppressor. It must be demanded by the oppressed'. Nigerians demonstrate internal vigilance and know that mere rehearse of human rights is meaningless unless it is linked with an affirmative action. Massive political education must become a desideratum at all levels of education, including families and the civil society. This is the only way human rights can translate to democratic development.

\section{References}

Akani, C. (2004). Globalization and the Peoples of Africa. Enugu, Fourth Dimension Publishers.

Ake, C. (1996). Democracy and Development in Africa. Abuja, Spectrum Books.

Ake, C. (1996). Is Africa Democratizing? Lagos, Malthouse Press Limited, Lagos.

Ake, C. (1981). A Political Economy of Africa. England, Longman.

Amunwo, K. (1998). Federalism and political Restructuring IN Nigeria (Ed.), Lagos, Spectrum books Limited.

Appadorai, A. (2004). The Substance of Politics, New Delhi, Oxford University Press.

Babawale, T. (2011). Pan Africanism and Integration of Continental and Diaspora Africa, Lagos, Center for Black and African Arts and Civilization.

Calloway, R. L., \& Harrelson, S. J. (2007). Exploring International Human Rights. London, Lynne Riennar Publishers.

Carmody, P. (2011). The New Scramble for Africa. Cambridge: Polity Press.

Dudley, B. (1982). Introduction to Nigerian Government and Politics. London, Macmillan

Dukor, M. (2003). Philosophy and Politics. Discourse on Values, Politics and Power in Africa. Lagos, Malthouse Press Limited.

Ekekwe, E. (1986). Class and State in Nigeria. Lagos, Longman.

Falola, T. (2002). Nigeria in the Twentieth Century. Durham, Carolina Academic Press.

Fanon, F. (1980). The wretched of the Earth. London, Penguin Books.

Guryev, D. (1990). The Riddle of the Origin of consciousness. Moscow: Progress Publishers.

Ibodje, S. (2001). Oil and the Niger Delta' in Governance and Politics in Nigeria. Ibadan, Spectrum Books .

Imogene, O. (1989). The Nigerian Class Structure. Lagos: Evans Brothers. Nig Publishers Ltd.

Kirilenko \& Korshunova. (1985). What is Philosophy. Moscow: Progress publishers.

Kukah, M. H. (2003). Democracy and Civil Society. Oxford, Spectrum books.

Laski, H. J. (2004). Grammar of Politics. New Delhi, Subject Publications.

Locke, J. (2004). Two Treaties of Government. London, Everyman Publication.

Maier, K. (2000). This House has Fallen, London: Penguin Book.

Marx \& Engels (1961). The Communist Manifesto. London: George Allen and UNWIN Ltd.

Marx, K. (1984). A Contribution to the Critique of Political Economy. Moscow, Progress Publishers.

Nault, D. M. (2009). Development in Asia. Interdisciplinary, Post-Neoliberal and Traditional 
Perspectives. Florida, Brown Walker Press.

Nnoli, O. (2003). Introduction to Politics. Enugu, SNAAP Press Ltd.

Nwoko, M. I. (1988). Basic World Political Theories, Owerri, Claretian Institute of Philosophy.

Omoregbe, J. I. (2003). Intellectual Giants and Moral Dwarfs in Education' in Philosophy and Politics, Discourse on Values and Politics in Africa. Lagos, Malthouse Press.

Odimegwu, et al. (2007). Philosophy, Democracy and conflicts in Africa, Owka, Fab Educational Books.

Ogbondah, C. (2003). State - Press Relations in Nigeria (1993-1998). Lagos, Spectrum Books.

Omoruyi, et al. (1994). Democratization in Africa. Nigeria Perspectives, vol. 1. Benin City; Hima \& Hima Ltd.

Onyesoh, C. I., \& Omeje, K. (2006). Stabilizing Nigerian Polity. Post military, Enugu, Institute for Development Studies.

Paine, T. (1996). Rights of Man, Cumberland, Wordsworth of Publication.

Peek, R., \& Hartpick, E. (1999). Theories of Development, London, The Guilford Press.

Remnick, D. (2011). The Life and Rise of Barack Obama. New York, Vintage books.

Rodney, W. (2009). How Europe Underdeveloped Africa. Lagos, Panaf Publishing.

White, L. W., \& Hussy, W. D. (1963). Government in Great Britain .Cambridge, Cambridge University Press.

\section{Copyright Disclaimer}

Copyright reserved by the author(s).

This article is an open-access article distributed under the terms and conditions of the Creative Commons Attribution license (http://creativecommons.org/licenses/by/3.0/). 